\title{
PERENCANAAN PERSEDIAAN BAHAN BAKU BROWNIS DENGAN MENGGUNAKAN METODE MATERIAL REQRUITMENT PLANNING (STUDI KASUS AA BREAD HOUSE)
}

\author{
N. Adityanti' ${ }^{1}$ A. Sahari ${ }^{2}$ \\ 1,2Program Studi Matematika Jurusan Matematika FMIPA Universitas Tadulako \\ Jalan Soekarno-Hatta Km. 09 Tondo, Palu 94118, Indonesia. \\ 1noviadtynt@gmail.com, 2agus_sh@yahoo.com
}

\begin{abstract}
AA Bread House shop, on Jalan Tanjung Pangipuan No.26, Palu City, Central Sulawesi. The shop sells brownies. The problem that often occurs in these stores is that they often experience shortages of raw materials. This resulted in many consumer demands not being fulfilled. With this problem, the shop must be able to predict how many brownies will be sold and how many raw materials will have to be provided in the following month. This study aims to forecast brownie sales at the AA Bread House store. Based on the data that has been obtained from the store, forecasting is done using the moving avarage method. From the forecasting carried out, the final results of the forecast for brownies in November 2020 were 530 boxes and the results of the net needs for brownis raw materials were coco moist 81000 grams, chocolate milk 93610 grams, eggs 56900 grams, 41000 grams oil, 157000 grams cheese, and colat filing. 101000 grams. December 2020 is 524 and the results of the need for cleaning raw materials for coco moist brownies are 104800 grams, chocolate milk 96940 grams, eggs 60784 grams, oil 52400 grams, cheese 157200 grams, and colat filing 106400 grams. January 2021 is 523 and the results need clean ingredients 104600 grams of coco moist brownis, 96755 grams of chocolate milk, 60668 grams of eggs, 52300 grams of oil, 156900 grams of cheese, and 104600 grams of colat filing.
\end{abstract}

\section{Keywords : Brownis, Forecasting, Moving Avarage Method, BOM, Lot For Lot Method}

\section{ABSTRAK}

Toko AA Bread House, di jalan Tanjung Pangipuan No.26, Kota Palu Sulawesi Tengah. Toko tersebut menjual brownis. Permasalahan yang sering terjadi pada toko tersebut adalah sering mengalami kekurangan bahan baku. Hal ini mengakibatkan banyak permintaan konsumen tidak terpenuhi. Dengan adanya permasalahan tersebut, pihak toko harus bisa meramalkan berapa banyak brownis yang akan terjual dan berapa banyak bahan baku yang harus disediakan pada bulan berikutnya. Penelitian ini bertujuan untuk melakukan peramalan penjualan brownis pada toko AA Bread House. Berdasarkan data yang telah didapatkan dari toko tersebut peramalan dilakukan dengan menggunakan metode moving avarage. Dari peramalan yang dilakukan, diperoleh hasil akhir peramalan untuk brownis bulan November 2020 yaitu 530box dan hasil kebutuhan bersih bahan baku brownis adalah coco moist 81000 gram gram, susu coklat 93610 gram, telur 56900 gram, minyak 41000 gram, keju 157000 gram, dan colat filing 101000 gram. Bulan Desember 2020 yaitu 524 dan hasil kebutuhan kebersih bahan baku brownis coco moist 104800 gram, susu coklat 96940 gram, telur 60784 gram, minyak 52400 gram, keju 157200 gram, dan colat 
filing 106400 gram.Bulan Januari 2021 yaitu 523 dan hasil kebutuhan kebersih bahan baku brownis coco moist 104600 gram, susu coklat 96755 gram, telur 60668 gram, minyak 52300 gram, keju 156900 gram, dan colat filing 104600 gram.

Kata Kunci : Brownis, Peramalan, Metode Moving Avarage, BOM, Metode Lot For Lot

\section{PENDAHULUAN}

Proses produksi merupakan kegiatan inti dari suatu perusahaan manufaktur. Dalam proses produksi, suatu perusahaan dituntut untuk menghasilkan suatu produk berkualitas yang sesuai dengan keinginan konsumen. Yang bertujuan untuk memperoleh laba dan mempertahankan eksistensinya. Agar mencapai tujuan tersebut suatu perusahaan perlu menyusun suatu perencanaan untuk menjamin kelancaran oprasional perusahaan. Salah satu faktor terpenting untuk menjamin kelancaran oprasional perusahaan adalah bahan baku yang optimum.

Ketersediaan bahan baku yang optimum dalam artian tidak banyak dan tidak sedikit karena keduanya mengandung resiko terkait kelancaran pelaksanaan proses produksi. Sehingga pabrik memerlukan suatu sistem persedian bahan baku. Namun demikian cara penyelenggaraan persediaan bahan baku akan berbeda-beda untuk setiap pabrik baik dalam hal jumlah unit maupun manajemen atau pengelola dari persediaan bahan baku dalam pabrik yang bersangkutan. Melihat realita yang sesuai dengan perkembangan pabrik yang semakin meningkat, maka diperlukan suatu pengelolaan dan perencanaan untuk dapat memenuhi permintaan. Tahap perencanaan langkah awal yang sangat penting untuk mencapai keberhasilan yang akan dicapai, juga dalam perencanaan bahan baku yang harus dilaksanakan sebaik-baiknya (Eddy Herjanto 2007).

Permasalahan yang sering dihadapi pabrik yang bergantung pada hasil produksi adalah perencanaan persediaan bahan baku yang kurang baik, sehingga mempengaruhi kelancaran operasional pabrik. Hal tersebut akan mengakibatkan proses produksi menjadi terlambat sehingga tidak mampu memenuhi permintaan pasar yang berdampak pada pabrik berupa kehilangan kesempatan untuk memperoleh sejumlah keuntungan yang diharapkan, berkurangnya kepercayaan pelanggan dan kerugian operasional seperti tenaga kerja dan mesin yang kurang produktif. Begitu juga sebaliknya, jika persediaan bahan baku berlebihan, maka pabrik akan mengalami tingginya biaya penyimpanan serta penggunaan investasi untuk persediaan bahan yang besar. Jika hal tersebut terjadi, maka dana untuk investasi di bidang lain akan berkurang. Selain itu, pabrik harus menanggung resiko penurunan kualitas. Secara umum dapat dikatakan bahwa biaya sistem persediaan adalah semua pengeluaran dan kerugian yang timbul sebagai akibat adanya pengadaan biaya sistem persediaan yang terdiri dari biaya pembelian, biaya pemesanan, biaya simpan dan persediaan. Sehingga untuk mencapai efisiensi biaya produksi perlu adanya suatu metode pengendalian sistem persediaan bahan baku metode tersebut adalah metode Material Reqruitment Planning (MRP) (Roger G.Schroeder, 1994). 
Material Requirement Planning (MRP) atau Perencanaan Kebutuhan Material merupakan suatu metode yang dimulai dengan kegiatan peramalan terhadap permintaan produk jadi yang independen, menentukan kebutuhan permintaan terikat untuk: (1) kebutuhan terhadap tiap jenis komponen (material, parts, atau ingredients), (2) jumlah pasti yang benar-benar diperlukan, dan (3) waktu membuat peramalan secara bertahap yang diperlukan untuk memenuhi 9 pesanan guna mencukupi suatu rencana produksi (Haming dan Nurnajamuddin, 2014). Roger G. Schroeder (1994) menyebutkan MRP sebagai suatu sistem informasi yang digunakan untuk merencanakan dan mengendalikan persediaan dan kapasitas.

Pabrik ini merupakan salah satu pabrik pembuat roti dan brownis, pabrik ini bertempat di jalan Tanjung Pangimpuan II no 26, Kelurahan Lolu Selatan Kecamatan Palu Selatan. Pabrik AA Bread House didirikan pada tahun 2016 dibawah pimpinan Ibu $\mathrm{Hj}$. Hasniani Celti. Permasalahan yang sering dihadapi pabrik adalah keterlambatan memenuhi permintaan pasar diakibatkan belum adanya sistem yang mengatur pembelian bahan baku sehingga terjadi penumpukan bahan baku dengan resiko penyusutan yang merugikan pabrik atau tidak tersedianya bahan baku yang mengakibatkan berhentinya produksi yang berujung pada ketidak mampuan pabrik memenuhi permintaan pasar.

\section{METODE PENELITIAN}

Metode dari penelitian ini adalah sebagai berikut:

a. Mulai penelitian

b. Mengkaji literatur

c. Mengambil data permintaan brownis, data harga bahan baku brownis, data persediaan bahan baku brownis, dan data biaya pesanan

d. Melakukan peramalan moving average

e. Perhitungan material reqruitment planning MRP

f. Hasil dan pembahasan

g. Kesimpulan dan saran

h. Selesai

\section{HASIL DAN PEMBAHASAN}

\subsection{Pengumpulan data}

1. Data Permintaan

Data permintaan dan pengumpulan data pada penelitian ini dapat dilihat pada Tabel 1.

Tabel 1 : Data Permintaan brownis bulan November 2019-Oktober 2020

\begin{tabular}{|c|c|}
\hline Bulan & Jumblah Permintaan \\
\hline November 2019 & 500 \\
\hline Desember 2019 & 492 \\
\hline
\end{tabular}




\begin{tabular}{|c|c|}
\hline Januari 2020 & 485 \\
\hline Februari 2020 & 522 \\
\hline Maret 2020 & 500 \\
\hline April 2020 & 503 \\
\hline Mei 2020 & 510 \\
\hline Juni 2020 & 500 \\
\hline Juli 2020 & 530 \\
\hline Agustus 2020 & 550 \\
\hline September 2020 & 525 \\
\hline Oktober 2020 & 515 \\
\hline
\end{tabular}

2. Data Persediaan

Data Persediaan dari AA Bread House dapat dilihat pada tabel 2 berikut

Tabel 2 : Data Persediaan Bahan Baku brownis

\begin{tabular}{|c|c|}
\hline Nama & Persediaan di tangan \\
\hline Choco moist & $25000 \mathrm{~g}$ \\
\hline Susu coklat & $4440 \mathrm{~g}$ \\
\hline Minyak kelapa & $12000 \mathrm{~g}$ \\
\hline Telur & $4500 \mathrm{~g}$ \\
\hline Coklat filling & $5000 \mathrm{~g}$ \\
\hline Keju & $2000 \mathrm{~g}$ \\
\hline
\end{tabular}

3. Data Bill Off Material (BOM)

Pembuatan BOM didasarkan pada struktur produk yang telah dibuat pada langkah sebelumnya. BOM merupakan tabel penjabaran dari struktur produk, yang memberikan data sebagai berikut : level tiap komponen, jumlah kebutuhan tiap-tiap komponen, serta sumber komponen tersebut. Tabel 4.3 ini merupakan BOM dari produk brownis per box.

Dari tabel tersebut dapat diketahui bahwa untuk menghasilkan produk brownis dibutuhkan : yang pertama, toping yang diperoleh dengan cara membeli dengan supplier, dan yang kedua yaitu adonan yang diperoleh dengan cara membeli dari supplier. Berikut tabel BOM :

Tabel 3 : Bill of Materials Produk Brownis per box

\begin{tabular}{|c|c|c|c|}
\hline Item & Level Komonen & Jumblah & Sumber \\
\hline Brownis & 0 & - & Buat \\
\hline Adonan & 1 & 1 unit & Proses \\
\hline Toping & 1 & 1 unit & Proses \\
\hline Choco moist & 2 & $200 \mathrm{gr}$ & Proses \\
\hline
\end{tabular}




\begin{tabular}{|c|l|l|l|}
\hline Susu coklat & 2 & $185 \mathrm{gr}$ & Proses \\
\hline Minyak & 2 & $150 \mathrm{gr}$ & Proses \\
\hline Telur & 2 & $116 \mathrm{gr}$ & Proses \\
\hline Keju & 2 & $300 \mathrm{gr}$ & Proses \\
\hline Coklat filling & 2 & $200 \mathrm{gr}$ & Proses \\
\hline
\end{tabular}

4. Data Harga Bahan Baku

Data harga bahan baku utama dalam pembuatan brownis dapat dilihat pada tabel 4 berikut :

Tabel 4 : Data harga Bahan Baku brownis

\begin{tabular}{|c|c|}
\hline Bahan baku & Harga \\
\hline Choco moist & Rp 550 000 \\
\hline Susu coklat & Rp 120 000 \\
\hline Minyak kelapa & Rp 160 000 \\
\hline Telur & Rp 150 000 \\
\hline Coklat filling & Rp 210 000 \\
\hline Keju & Rp 100 000 \\
\hline
\end{tabular}

5. Data persediaan dan lead time

Tabel 5 : Data lead time

\begin{tabular}{|c|c|}
\hline Bahan baku & Lead time \\
\hline Choco moist & 1 \\
\hline Susu coklat & 1 \\
\hline Minyak kelapa & 1 \\
\hline Telur & 1 \\
\hline Coklat filling & 1 \\
\hline Keju & 1 \\
\hline
\end{tabular}

Keterangan :

Persediaan bahan baku yang dimililki AA Bread House dan lead time maka dalam perhitungan MRP bahan baku persediaan ini sebagai batasan untuk perencanaan pemesanan bahan baku kedepannya.

6. Biaya Pemesanan

Biaya Pemesanan (Ordering cost, procurement cost) adalah biaya yang dikeluarkan sehubungan dengan kegiatan pemesanan bahan atau barang, sejak dari penempatan pemesanan sampai tersedianya barang digudang. Biaya untuk pemesanan bahan baku mencakup biaya transportasi. Biaya pemesanan untuk bahan baku dapat dilihat sebagai berikut:

Biaya transportasi : Rp 50.000,00. 


\subsection{Pengolahan Data}

Setelah data yang diperlukan didapat maka dilakukan pengolahan data sesuai dengan taksiran metode peramalan dan Material Requirment Planning (MRP) ditampilkan pada Gambar 1.

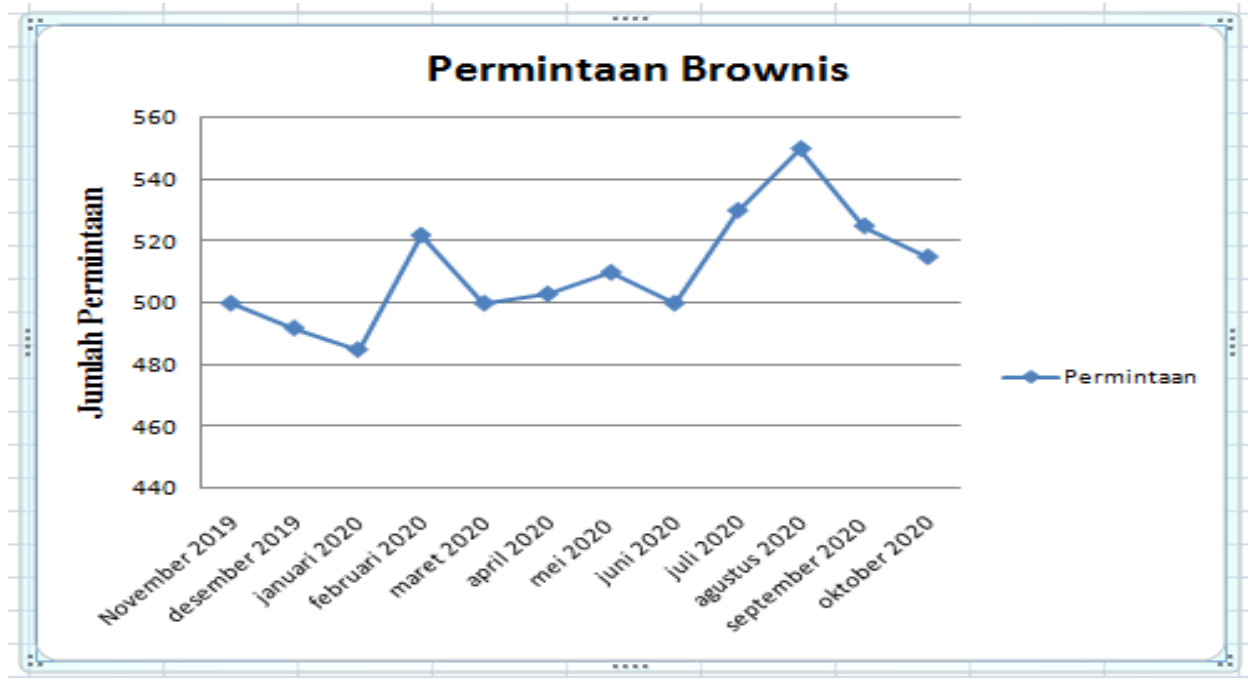

Gambar 1 : Plot Data Permintaan brownis Bulan November 2019-Oktober 2020

1. Peramalan

Metode peramalan yang digunakan berdasarkan plot data permintaan masa lalu yang didapat dari AA Bread House maka metode yang dapat digunakan adalah metode peramalan Moving Average.

Peramalan yang akan dilakukan di sini adalah selama 3 bulan, karena jika menggunakan peramalan terlalu lama hasilnya semakin tidak akurat. Berdasarkan plot data permintaan masa lalu pada Gambar 4.1, dapat dilihat bahwa permintaan tersebut terjadi secara acak. Menurut Lindawati (2003) permintaan yang memiliki pola acak menggunakan metode peramalan Moving Average.

Metode Moving Average (MA) merupakan metode yang merata-ratakan permintaan berdasarkan beberapa data masa lalu yang terbaru. Adapun metode Moving Average (MA) dapat dinyatakan dalam persamaan sebagai berikut:

$$
M=\frac{A_{t}+A_{t-1}+\cdots+A_{t-(N-1)}}{N}
$$

Dimana:

$A=$ Permintaan Aktual pada periode $-t$

$\mathrm{N}=$ jumlah data permintaan yang dilibatkan dalam perhitungan

Adapun pemilihan nilai $\mathrm{N}$ yang digunakan pada penelitian ini adalah rata-rata bergerak 3 bulanan. Dimana ini digunakan karena permintaan produk dari waktu 
ke waktu mengalami fluktuasi yang signifikan, maka dalam mengantisipasi permintaan ini peramalan harus cukup agresif. Sehingga peramalan dengan nilai $\mathrm{N}$ yang kecil akan lebih cocok (Nasution dan Prasetyawan, 2008:42).

Tabel 6 : Perhitungan Peramalan Permintaan brownis Dengan Metode Moving Average (MA)

\begin{tabular}{|c|c|c|}
\hline Bulan & Permintaan & Peramalan \\
\hline November 2019 & 500 & $(550+525+515) / 3=530$ \\
\hline Desember 2019 & 492 & $(525+515+530) / 3=524$ \\
\hline Januari 2020 & 485 & $(515+530+524) / 3=523$ \\
\hline Februari 2020 & 552 & - \\
\hline Maret 2020 & 500 & - \\
\hline April 2020 & 503 & - \\
\hline Mei 2020 & 510 & - \\
\hline Juni 2020 & 500 & - \\
\hline Juli 2020 & 520 & - \\
\hline Agustus 2020 & 550 & - \\
\hline September 2020 & 525 & - \\
\hline Oktober 2020 & 515 & - \\
\hline
\end{tabular}

Dengan hasil peramalan dengan menggunakan metode Moving average (MA) diatas, maka langkah yang selanjutnya dilakukan adalah melakukan akurasi hasil peramalan. akurasi hasil peramalan ini dilakukan bertujuan untuk mengetahui ukuran kesalahan peramalalan berdasarkan tingkat perbedaan antara hasil peramalan dengan permintaan yang sebenarnya terjadi. Dimana ukuran akurasi ini yang digunakan adalah MAD ( mean absolute deviation), MSE (meansquare error), dan MAPE (mean absolute percentage error). Adapun perhitungan ukuran akurasi hasil peramalan yang dilakukan pada peramalan moving average (MA) ditunjukkan pada Tabel 7. 
Tabel 7 : Hasil Perhitungan Ukuran Akurasi Peramalan

\begin{tabular}{|c|c|c|c|c|c|c|c|}
\hline No & $\begin{array}{c}\text { Permintaan } \\
\qquad|\mathrm{A}|\end{array}$ & $\begin{array}{l}\text { Peramalan } \\
\qquad|\mathrm{F}|\end{array}$ & $\begin{array}{l}\text { Deviasi } \\
|A-F|\end{array}$ & $\begin{array}{l}\text { Deviasi } \\
\text { absolut } \\
|A-F|\end{array}$ & $\begin{array}{l}\text { Kuadrat } \\
\text { kesalahan } \\
(A-F) 2\end{array}$ & $\begin{array}{l}\text { Persentase } \\
\text { kesalahan } \\
(\mathrm{A}-\mathrm{F} / \mathrm{A}) 100\end{array}$ & $\begin{array}{l}\text { Persentase } \\
\text { kesalahan } \\
\text { absolut } \\
\text { |A - F/A 100| }\end{array}$ \\
\hline 1 & 500 & 530 & -30 & 30 & 60 & -6 & 6 \\
\hline 2 & 492 & 524 & -32 & 32 & 64 & $-6,50$ & 6,50 \\
\hline 3 & 485 & 523 & -38 & 38 & 76 & $-7,83$ & 7,8 \\
\hline 4 & 552 & - & - & - & - & - & - \\
\hline 5 & 500 & - & - & - & - & - & - \\
\hline 6 & 503 & - & - & - & - & - & - \\
\hline 7 & 510 & - & - & - & - & - & - \\
\hline 8 & 500 & - & - & - & - & - & - \\
\hline 9 & 520 & - & - & - & - & - & - \\
\hline 10 & 550 & - & - & - & - & - & - \\
\hline 11 & 525 & - & - & - & - & - & - \\
\hline 12 & 515 & - & - & - & - & - & - \\
\hline 13 & TOTAL & & & $=100$ & $=200$ & & $=20,55$ \\
\hline \multicolumn{8}{|c|}{$\begin{array}{l}\text { MAD }=\sum\left|\frac{A_{t}-F_{t}}{n}\right|=\frac{100}{3}=33,34 \\
\text { MSE }=\sum \frac{\left(A_{t}-F_{t}\right)^{2}}{n}=\frac{200}{3}=66,67 \\
\text { MAPE }=\left(\frac{100}{n}\right)^{2} \sum\left|A-\frac{A_{t}}{F_{t}}\right|=\frac{20,55}{3}=6,85 \%\end{array}$} \\
\hline
\end{tabular}

2. Master Production Schedules (MPS)

MPS (Master Production Schedules) mewakili sebuah rencana untuk pelaksanaan produksi. MPS dibuat berdasarkan hasil forecasting dan pesanan konsumen. Karena produksi di AA Bread House adalah Mass Production, maka MPS yang dibuat hanya berdasarkan forecasting saja.

Tabel 8 : Master Production Schedules brownis November 2020-Januari 2011

\begin{tabular}{|l|l|}
\hline Bulan & Jumblah permintaan per box \\
\hline November 2020 & 530 \\
\hline Desember 2020 & 524 \\
\hline Januari 2011 & 523 \\
\hline
\end{tabular}

3. Penghitungan Jumlah Kebutuhan Bersih

Dari data MPS mingguan yang juga merupakan kebutuhan kotor dapat diketahui kebutuhan bersih (net requirement) dengan mengurangi kebutuhan kotor (gross requirement) dengan persediaan yang dimiliki (on hand). Kebutuhan bersih ini merupakan banyaknya produk, part atau item yang harus diproduksi setiap periode untuk memenuhi pesanan konsumen. Dengan mengasumsikan bahwa dalam 1 bulan terdapat 4 minggu. maka dapat dibuat kebutuhan bersih untuk 
produk maupun untuk part atau item. Dengan melihat BOM, sehingga kita dapat menghitung kebutuhan bersih untuk brownis dan tiap bahan bakunya.

Berdasarkan data persediaan awal dan jumlah kebutuhan kotor, maka dapat dihitung berapa jumlah kebutuhan bersih per minggu. Hasil perhitungan kebutuhan bersih nantinya akan digunakan sebagai dasar untuk menghitung jumlah lot setiap kali pembelian dilakukan. Berikut hasil perhitngan kebuthan bersih :

Tabel 9 : Hasil Akhir Penghitungan Jumlah Kebutuhan Bersih

\begin{tabular}{|l|l|}
\hline Item & Jumblah kebutuhan bersih \\
\hline Brownis & 1577 box \\
\hline Choco moist & 290400 gram \\
\hline Susu coklat & 287305 gram \\
\hline Telur & 178352 gram \\
\hline Minyak & 139700 gram \\
\hline Keju & 471100 gram \\
\hline Coklat filling & 312000 gram \\
\hline
\end{tabular}

4. Penghitungan Lot Sizing

Setelah diketahui jumlah unit kebutuhan bersih untuk tiap-tiap bahan baku,maka perlu direncanakan pembelian bahan baku tersebut. Perencanaan pembelian bahan baku dilakukan dengan cara menentukan jumlah dan waktu pembelian yang optimal untuk tiap-tiap pembelian. Pada penelitian ini, penentuan jumlah dan waktu pembelian masing-masing bahan baku akan dihitung dengan menggunakan metode lot for lot. Pada penghitungan Lot for Lot, pembelian bahan baku dilakukan sesuai dengan jumlah kebutuhan bahan baku tiap minggu. Biaya yang timbul pada metode ini hanya biaya pemesanan, karena bahan baku tidak sampai pada tahap penyimpanan.

Tabel 10 : Hasil Perhitungan MRP Metode Lot For Lot

\begin{tabular}{|l|l|l|l|}
\hline Periode & November & Desember & Januari \\
\hline GR (kebutuhan kotor) & 530 & 524 & 523 \\
\hline OH (persediaan) & - & - & - \\
\hline NR (kebutuhan bersih) & 530 & 524 & 523 \\
\hline PORec (perencanaan pemesanan) & 530 & 524 & 523 \\
\hline PORel (penerimaan pesanan) & 530 & 524 & 523 \\
\hline
\end{tabular}


Total GR (kebutuhan kotor) $=1577$

Total $\mathrm{OH}$ (persediaan $)=0$

Biaya Pemesanan $=3 \times 50.0000=150.000$

Metode lot sizing tersebut bergantung pada jumlah kebutuhan bahan baku, juga apabila terjadi perubahan kebijakan mengenai biaya ataupun perubahan harga bahan baku. Semua hal tersebut mempengaruhi jumlah penghitungan pada lot sizing, oleh karena itu perlu ditentukan masa periode perencanaan kebutuhan bahan baku. Dimana setelah satu masa periode perencanaan selesai, maka perlu dihitung ulang jumlah lot pembelian bahan baku. Apabila perubahan terjadi dalam masa perencanaan, maka lot sizing juga tetap perlu dihitung ulang untuk menjaga keakuratan hasilnya.

\section{KESIMPULAN}

Perencanaan persediaan kebutuhan bahan baku dihitung berdasarkan peramalan yang telah dilakukan menggunakan metode MRP (material reqruitmen planning). Sehingga diperoleh jumlah data peramalan permintaan brownis bulan November 2020 yaitu 530box dan hasil kebutuhan bersih bahan baku brownis adalah coco moist 81000 gram gram, susu coklat 93610 gram, telur 56900 gram, minyak 41000 gram, keju 157000 gram, dan colat filing 101000 gram. Bulan Desember 2020 yaitu 524 dan hasil kebutuhan kebersih bahan baku brownis coco moist 104800 gram, susu coklat 96940 gram, telur 60784 gram, minyak 52400 gram, keju 157200 gram, dan colat filing 106400 gram.Bulan Januari 2021 yaitu 523 dan hasil kebutuhan kebersih bahan baku brownis coco moist 104600 gram, susu coklat 96755 gram, telur 60668 gram, minyak 52300 gram, keju 156900 gram, dan colat filing 104600 gram. Dan hasil perhitungan biaya pemesanannya adalah Rp 150.000,00.

\section{DAFTAR PUSTAKA}

[1]. Astana, I Nyoman Yudha. Perencanaan Persediaan Bahan Baku Berdasarkan Metode MRP (Material Requirement Planning). Fakultas Teknik Universitas Udayana, 2007, Denpasar.

[2]. Hartini, Sri. PPC : Production Planning and Control. Laboratorium Sistem Produksi Teknik Industri UNDIP, 2006, Semarang. Edisi ketiga.

[3]. Heyzer, Jay dan Barry Render. Operations Management : Manajemen Operasi. Salemba Empat, 2005, Jakarta. Buku 2. Edisi Ketujuh.

[4]. Herjanto, Eddy. Manajemen Operasi. Penerbit Grasindo, 2007, Jakarta.

[5]. Haming, Murdifin dan Mahmud Nurnajamuddin. 2014. Manajemen Produksi Mordern: Operasi Manufaktur dan Jasa. Bumi Aksara , 2014, Jakarta. Buku Dua Edisi Kedua. 
[6]. Lindawati. Perencanaan bahan baku di CV. Solindo Tama. Universitas Kristen Petra, 2003, Surabaya.

[7]. Nasution, A. Hakim dan Prasetyawan, Yudha. Perencanaan \& Pengendalian Produksi. Penerbit Graha IImu , 2008, Yogyakarta.

[8]. Rovianty, Andi Novi. (2007). Analisis Penerapan Material Requirement Planning (MRP) dalam Upaya Mengendalikan Persediaan Bahan Baku Daging Pada Long Horn Steak \& Ribs. Fakultas Bisnis dan Manajemen, Universitas Widyatama, 2007, Bandung.

[9]. Schroeder, Roger G.(1994). Manajemen Operasi : Pengambilan Keputusan dalam Suatu Fungsi Operasi. Erlangga, 1994, Jakarta. Jilid 2, Edisi Ketiga.

[10]. Tampubolon, Manahan P. Manajemen Operasi (Operations Management). Ghalia Indonesia , 2004, Jakarta.

[11]. Wiranata, Riyanti. Penerapan Sistem Material Requirements Planning (MRP)Sebagai Alat Untuk Meningkatkan Efisiensi Biaya Persediaan Bahan Bakupada PT. Siantarjaya Ekatama Surabaya. Universitas Kristen Petra, 2002, Surabaya. 